Mark Edwards

\title{
Evil in Dionysius the Areopagite, Alexander of Hales and Thomas Aquinas
}

\begin{abstract}
This paper examines Alexander of Hales' use and reconciliation of apparently dissonant quotations from Dionysius on two related questions, the knowability of God and the origin of evil. Noting that Alexander, as a junior colleague of Robert Grosseteste, was one of the first to make extensive use of Dionysius, it shows that he normally cites him in conjunction with Augustine and other Latin writers rather than according an independent authority to him. It is also argued that, although Alexander in some respects anticipates the conclusions of Aquinas, which are also reinforced by appeals to Dionysius, he is more inclined to admit the substantiality of evil.
\end{abstract}

Theology is distinguished from philosophy, not only by its loftier subject-matter, but by its principled subordination of reason to tradition in the investigation of that subject-matter. No professing Christian before the $18^{\text {th }}$ century called the inerrancy of the Scriptures into question, and any church that purported to be catholic held fast to the decrees of at least four oecumenical councils, while according presumptive authority also to certain individuals whom it esteemed as fathers, doctors or apologists for the true faith. For the scholastics Augustine was the cynosure of a Latin constellation whose lesser stars were Hilary, Ambrose, Jerome, Gregory the Great, Isidore of Seville and (by about 1200) as recent a saint as Anselm; they too, if less often quoted, were not to be contradicted, and the same was true of the easterners John Chrysostom and John Damascene, who were now and then co-opted (through Latin versions) to give the stamp of universality to the same truths. We should not infer that all originality was precluded: authority might determine what the church was to believe, but not what means of proving it might be employed by a given exponent, while there were numerous corollaries and implications of these normative tenets on which it was possible for good Christians to differ. To be original meant not so much to establish new beliefs as to show, with unprecedented clarity and fullness, what had always been involved in the belief of the church from the time of the apostles.

We need not wonder, therefore, that the Dionysian corpus was adopted with such eagerness by the more innovative thinkers of the $12^{\text {th }}$ century. The author by his own account was among the first neophytes of the apostle Paul, while in reality he was the very model of a scholastic, bringing forth thoughts that were new to the church of his epoch under cover of high antiquity, and mingling the discourses of Paul and Plato as his mediaeval admirers called on Aristotle to ratify pronouncements which had already met the test of orthodoxy. Among these latter-day pupils of the Stagirite, Dionysius sometimes claims an authority second only to that of Augustine; this is evident above all in their appeals to the Dionysian excursus on the nature of evil, 
which is at once the author's most extensive plagiarism from the Greeks and one of his most seminal contributions to the speculative thought of the Middle Ages. As a preface to scrutiny of the relevant passages in the Summa Halensis, I shall briefly review the content of the Dionysian corpus and the history of its reception in the west before Alexander; the paper will conclude with a note on the application of the same texts to similar questions in Aquinas' essay on evil, which, while it is undoubtedly the work of a greater scholar and logician, might not have been the work that it is had he not been able to build on the groundwork laid by his predecessor.

\section{The Dionysian Corpus}

The Dionysian corpus is a body of Greek texts, consisting in its present form of five works, the Divine Names, the Celestial Hierarchy, the Ecclesiastical Hierarchy, the Mystical Theology and ten Epistles. ${ }^{1}$ These works make occasional reference to other works by the same hand, which for all that we know are fictitious. Even those that remain are not what they purport to be, for while the author professes to be Dionysius (or Denys) the Areopagite, Paul's convert at Acts 17:34, ${ }^{2}$ his lucubrations were entirely unknown before the first quarter of the $5^{\text {th }}$ century. Moreover, both his vocabulary and his metaphysical premisses are patently indebted to Proclus, a Platonist of the $5^{\text {th }}$ century, whose teaching on providence is at times transcribed almost word for word in an excursus on the origin of evil in the fourth book of the Divine Names. ${ }^{3}$ Recent scholarship has also brought to light his affinities with Damascius, another Athenian Platonist who is likely to have been an exact contemporary of the author. ${ }^{4}$ Ancient and modern readers who were able to make the comparison surmised that it was the Platonists who had embraced the theology of Dionysius; no modern commentator with any historical sense, however, will suppose that the

1 The standard modern edition is Corpus Dionysiacum, vol. 1, De Divinis Nominibus (hereafter, DN), ed. Beate Regina Suchla; vol. 2, De Coelesti Hierarchia, De Ecclesiastica Hierarchia, De Mystica Theologia, Epistulae, ed. Günter Heil and Adolf Martin Ritter, Patristische Texte und Studien, 33, 36 (Berlin: De Gruyter, $1990-1)$.

2 On the significance of the pseudonym in its relation to Acts 9:3, 2 Cor. 12:4 and above all Acts 17:23, see Charles M. Stang, Apophasis and Pseudonymity in Dionysius the Areopagite (New York: Oxford University Press, 2012).

3 Hugo Koch, Pseudo-Dionysius Areopagita in seinen Beziehungen zum Neuplatonismus und Mysterienwesen (Mainz: Kirschheim, 1900); and especially Josef Stiglmayr, 'Der Neuplatoniker Proklos als Vorlage des sog. Dionysius Areopagita in der Lehre von Übel,' Historisches Jahrbuch 16 (1895): $253-73$.

4 Carlo Maria Mazzucchi, 'Damascio, autore del Corpus Dionysiacum, e il dialogo Peri politikês epistemês,' Aevum 80 (2006): 299-34. For a more temperate estimate of the author's debt to the Athenian school, see Sarah Klitenic Wear and John M. Dillon, Dionysius the Areopagite and the Neoplatonist Tradition (Aldershot: Ashgate, 2007). 
church was able to develop thoughts of such rigour and complexity in the 1st century, or that having done so it would have let them fall into 400 years of desuetude.

The author is by his own profession a Christian, quoting far more than anyone in the apostolic age would have been able to quote from the corpus that we now know as the New Testament, and lapsing into patent anachronism with his citations from Ignatius and from Clement of Alexandria. The corpus was none the less accepted as genuine in the Middle Ages, and Papal claims were partially grounded in the Ecclesiastical Hierarchy. John of Scythopolis added Glosses, which were often translated along with the corpus in the Western tradition. ${ }^{5}$ The commentaries of Maximus the Confessor were also frequently consulted. In the $9^{\text {th }}$ century, John Scotus Eriugena translated the corpus into a language so heavily calqued on the Greek that it was at times barely recognisable as Latin. ${ }^{6}$ Abbot Hilduin of St Denys seems to have revised this version to render it more readable, but without personal knowledge of Greek. ${ }^{7}$ Between 1130 and 1160 John Sarracenus (probably a Greek speaker) translated the corpus into more lucid Latin, correcting some of Eriugena's errors. His translation was the basis of the Glosses of Thomas Gallus on the Mystical Theology, ${ }^{8}$ as well as of the English treatise of the $14^{\text {th }}$ century, Denys Hid Divinite, which comes from the same hand as the Cloud of Unknowing. ${ }^{9}$

Five fatherless texts had thus become the cornerstone of Western mysticism, although no word for this phenomenon had yet been coined and the author himself would not now be regarded as one of its typical exemplars. So much was apparent already to the contemplative author of Denys Hid Divinite (most probably a Carthusian) who supplements the translation of Sarracenus with his own regimen for emptying the mind of its everyday lumber and attaining a transcendental mode of cognition. By contrast, the chief objective of the Dionysian corpus is not to give precepts for achieving immediate knowledge of God, but to reconcile the anthropomorphic language of Scripture with the philosophic principle that God is known best through negation of all predicates. This apophatic mode of apprehension must be balanced by the kataphatic mode, derived from Scripture, in which some terms represent qualities which God possesses 'super-eminently', while others must be understood sym-

\footnotetext{
5 Paul Rorem and John C. Lamoreaux, John of Scythopolis and the Dionysian Corpus: Annotating the Areopagite (New York: Oxford University Press, 1998).

6 On his habit of passing from 'word to word or even form syllable to syllable, without paying much heed to the drift of his author's argument', see Philip Levine, 'Two Early Latin Versions of St Gregory

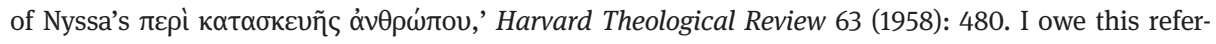
ence to Lydia Schumacher.

7 G. Thery, 'Jean Sarrazin, traducteur de Scot Erigène,' in Studia mediaevalia in honorem admodum reverendi patris R. Martin (Bruges: Du Tempel, 1948), 359-81.

8 James McEvoy, Mystical Theology: The Glosses by Thomas Gallus and the Commentary of Robert Grosseteste on 'De Mystica Theologia' (Leuven: Peeters, 2003). See also Gallus, Commentaire du Cantique des Cantiques, ed. Jeanne Barbet (Paris: Vrin, 1967).

9 See further Cheryl Taylor, 'The Cloud-Author's Remaking of the Pseudo-Dionysius' Mystical Theology,' Medium Aevum 75 (2006): 202-18.
} 
bolically. Modern research has stressed the liturgical context implied by the hierarchical treatises and the author's indebtedness to the ascetic tradition. ${ }^{10}$ Protestant readings have until recently concentrated on the 'mysticism' of the Divine Names and Mystical Theology, thereby exaggerating (with approval or disapproval) the common ground between its religiosity and that of the pagan schools.

We are less inclined to characterize this alleged disciple of Proclus as a philosopher, though this is the garb in which he was presented by Robert Grosseteste, one of Oxford's earliest teachers in theology, who probably encountered the corpus during his sojourn in Paris. ${ }^{11}$ A man of great parts, who may have been Chancellor of the University and left it to become the Bishop of Lincoln, Grossesteste favoured the study of primary texts against the new custom of basing all disputation on the Sentences of Peter Lombard. ${ }^{12}$ In an age when few were polyglots, he acquired a sufficient knowledge of Greek to translate not only the Dionysian writings but also the letters of Ignatius, thus preserving the substance of the most authentic recension of the latter for the 300 years during which the Greek was lost. For all his endeavours to grasp the whole scheme of things in one imaginative vision, ${ }^{13}$ Grossesteste was in the modern sense no mystic, and his rendering was less serviceable than that of Sarracenus to the interests of his Victorine friend Thomas Gallus. Where Gallus maintains in his Commentary on the Song of Songs that love supplants reason as we approach the ineffable, Grossesteste cannot deny reason a place in the apprehension of God. Certainly the quest entails the purgation of sense and intellect, but the darkness to which it escorts us is itself a mode of light, as Dionysius testifies at Divine Names 4.4. Thus he confirms the ubiquitous teaching of the English scholar, that the essence of the intellectual realm is a supernal light which passes through a series of devolutions to appear at last as a sensible emanation from the sun, by which we see both the sun itself and all other bodies. Although his translation did not come into immediate use, ${ }^{14}$ Grosseteste communicated his high esteem for the Areopagite to two other Englishmen, his friend Adam Marsh (the author, some think, of the Glosses on the Mystical Theology which are attributed to Gallus ${ }^{15}$ ), and his junior colleague at the university, the Greekless but indefatigable Alexander of Hales. ${ }^{16}$

10 Andrew Louth, Denys the Areopagite (London: Geoffrey Chapman, 1989); Alexander Golitizin, Mystagogy: A Monastic reading of Dionysius Areopagita (Dubuque, IA: Cistercian Publications, 2013). 11 See James McEvoy, Robert Grosseteste (Oxford: Oxford University Press, 2000), 16, also 117-20 on Grosseteste as translator.

12 In this he was not followed by Alexander; see McEvoy, Grosseteste, 160-2.

13 See Robert Grosseteste, Templum Dei, ed. and trans. Josef Goering and Frank Anthony Carl Mantello (Toronto: Pontifical Institute of Medieval Studies, 1984).

14 Thus in Summa Halensis (see below, n. 18) Vol 3, In1, Tr1, Hales reads adversaria at DN 4.20, with Sarracenus, rather than repugnantia, as in Groesseteste.

15 See McEvoy, Mystical Theology, 125.

16 I use his name by courtesy, but the source for this part of the Summa Halensis appears to be John of La Rochelle’s Summa de Vitiis: see D.O. Lottin, 'Alexandre de Halès et la "Summa de Vitiis" de Jean de la Rochelle,' Recherches de théologie ancienne et mediévale 1 (1929): 240-3. 


\section{The Great Questions}

But what would an English scholar of the early $13^{\text {th }}$ century gain by reading Dionysius, at a time when some still doubted whether one could read Aristotle and be saved? While Aristotle was the most esteemed of the Greek philosophers, the intellectual lodestar of the Western church was Augustine, who was also its permanent touchstone of orthodoxy. Dionysius, alone of the Eastern fathers, was a philosopher of comparable stature; his debt to Proclus, according to modern estimates, outweighed even that of Augustine to Plotinus, though it may be that Alexander's contemporaries, unaware that the Liber de Causis was based on the Elements of Theology by Proclus, were reading the latter unwittingly as an Aristotelian counterpoint to Augustine's Platonism. The Victorines of the $12^{\text {th }}$ century, impressed above all by the Celestial Hierarchies, made Dionysius the bedrock of their mystical commentaries; the philosophical synthesis of Augustine and Dionysius was above all the work of Parisian theologians, culminating in the Summa Theologiae of Aquinas, together with his commentaries on the Liber de Causis and on the Divine Names. We must not underestimate the difficulties which lie in the way of such a synthesis. The very fact that Augustine is, if anything, more of a mystic than Dionysius-that is, more apt to dwell on the perturbations and ecstasies of the interior life-gives a more introspective character to his thought, whether he is meditating on his own acts of memory in the hope of bringing to light the nature of time or demonstrating that the first, and only free, transgression of Adam is the ineluctable cause of moral corruption in all his progeny save One. Just as he perfectly illustrates, and indeed is largely responsible for, the forensic tendency in Latin thought, so Dionysius exemplifies what we may call the doxological tendency of the Eastern tradition, for which the capital question is, not 'How can I be saved?' but 'Whom do I worship?'

We look in vain through the multitudinous writings of Augustine for the rich ecclesiology and the detailed angelology that occupy two of the five books in the Dionysian corpus; ${ }^{17}$ conversely, when we read Dionysius on evil, we may feel that he concedes everything to the Platonists who ascribe not only evil but our perception of it to ignorance, betraying no sense of the gravity of sin, and no experience of that struggle between the spirit and the flesh which had prompted Paul to cry out 'Wretched man that I am!' When all account is taken of the manifold adumbrations of his teaching in the liturgies, the ascetic disciplines and the theological reflections of the Eastern church, it can be argued without absurdity that the incarnation of Christ is of only passing interest to him, that he worships an impersonal Godhead rather than the one God in three persons, and that his apophatic theology permits him to make

17 Lydia Schumacher points out to me that the treatise De Angelis in the Summa Halensis draws heavily on the Celestial Hierarchies of Dionysius. See also Mark J. Edwards, 'Aquinas on Ephesians and Colossians,' in Aquinas on Scripture, ed. Thomas G. Weinandy, Daniel A. Keating, and John P. Yocum (London: A. and C. Black 2005), 149-65. 
what he will of Scripture-in short, that he is essentially a Platonist, and that even his best thoughts, such as his apparent universalism, are rendered possible only by his refusal to bow, as Augustine does, to the ineluctable consequences of linear and literal exegesis. Again it can be argued that his most famous gift to Christian thought-his proclamation that God is not one being among other beings, to be circumscribed by any distension of the human intellect or by any word that human speech can furnish-was already a commonplace of the Latin tradition, from Novatian to Augustine. All this being true, it is clear none the less that once it entered Western thought the Dionysian strain could not be removed from it, not only because it gave apostolic warrant to the practice of philosophy but because it cemented the ratiocinative with the devotional faculties, the seeking of God with the service of his Word, in a manner that was rather foreshadowed than accomplished even in Augustine. In his determination to marry the two, Alexander laid the foundation for the work of and was a true precursor to Aquinas, and never more so than in his meditations on the nature of being and in the origin of that aberration from being to which Augustine and Dionysius alike had given the name of evil.

We shall now consider the role of Dionysius in the solution of three questions which are posed by Alexander. The first, as to whether evil has a principle, appears to have been conflated with the question whether evil has a principle. The second, which concerns the existence of evil, is partly anticipated by the negative reply to the first, while the third, regarding the provenance of evil, is as much a recapitulation of the two foregoing questions as a logical successor. While Alexander's division of his material no doubt requires some explication, the present paper sets itself the more limited object of illustrating his efforts to harmonize Dionysian teaching on the one hand with Aristotelian metaphysics and on the other with the Latin tradition stemming from Augustine.

\section{Is Evil a Principle? ${ }^{18}$}

Any attempt to explain the presence of evil in the created world must commence with an inquiry into the rationale of creation. Alexander undertakes this in Book 2 Part 1 Section 1 of the Summa: 'on creation according to cause'. The rubric of the first question is 'on the first cause according to substance'. We shall paraphrase the argument according to the heads under which it is divided in the Summa:

18 All citations of Alexander are from Alexander of Hales, Doctoris irrefragabilis Alexandri de Hales Ordinis minorum Summa theologica (SH), 4 vols (Quaracchi: Collegium S. Bonaventurae, 1924-48). 


\section{Head 1: 'is there a principle of all things?'}

The answer, as ever, is already determined at the outset, for the argument that the mutable must be grounded in the mutable is upheld by Isidore of Seville and by John Damascene, two authors of unimpeachable orthodoxy. ${ }^{19}$ The fact that both are encyclopaedists may explain why they, and not more innovative thinkers, have been summoned as witnesses to a universal platitude.

\section{Head 2: 'what kind of thing is the first principle?'}

This is a question more open to debate, and, while we have Damascene's testimony that the answer cannot be known in via (that is, under the conditions of a fallen world), ${ }^{20}$ we must turn to Dionysius to learn the reason for this proviso. His major premiss, ${ }^{21}$ advanced as a tautology, is that any being which is beyond contemplation and comprehension must be inapprehensible by the senses; anyone familiar with his writings will be able to supply the minor premiss that the superessential God is such a being. Hence it follows that he must be inapprehensible to all sensory powers, just as it follows that, since he is the Good that surpasses all reason, he cannot be an object of reason. Alexander seems to assume that we know the first principle to be God: a second quotation from Dionysius reinforces the lesson that he or it is super-unknowable and cut off from all because he or it cannot be thought of, expressed or in any manner contemplated. ${ }^{22}$

So far we have heard little more than asseveration. Alexander himself does the work of proof by showing that none of the five modes of predication acknowledged by Aristotle is applicable to the first cause. When he quotes Dionysius again, it is not to corroborate this reasoning but to bring up an objection: does not the great doctor witness against himself when he deduces from Rom. 1:20 that God is the being, the life, the cause and principle of all? ${ }^{23}$ This intimation that God is knowable after all is verified by Augustine's description of him as the light who makes himself visible, while Aristotle (or rather Avicenna) completes the triad by characterizing being as that which makes the first impression on the intellect. ${ }^{24}$ If we assume the identity

19 SH II (n. 1), p. 2a, citing Isidore, Sentences 1.1.13 and Damascene, On the Orthodox Faith 1.3. I do not ask here whether Alexander is always faithful to Isidore and Damascene in his citations; even his misrepresentations, of course, pay tribute to their authority.

20 SH II (n. 1), p. 2a, citing Damascene, On the Orthodox Faith 1.4, though the distinction between truth in via and truth in patria belongs to the scholastic era.

$21 S H$ II (n. 2), p. 2b, citing $D N 1.1$.

22 DN 1.5 (Suchla, 115.11-15).

$23 S H$ II (n. 2), p. 3b, citing DN 1.3 (Suchla, 111.12-13).

24 Augustine, On the Trinity 4.28; Avicenna, Commentary on the Metaphysics 1.5. 
of God and being, it seems that the foremost philosophers agree in declaring him to be an object of cognition.

And yet, since they are the foremost, they must concur not only with one another, but with their own teachings elsewhere and with the received position of the church. The solution is that the one who is unknowable in via is none the less knowable in patria, that is, in our proper place: as Scripture itself assures us, a day will come when 'we shall see him as he is' (1 John 3:3). Because the knowledge of which Aristotle and Augustine speak is not immediately available to us in via, God is rightly said to be unknowable in substance. According to his affects, however, he can be known, as Dionysius explains. ${ }^{25}$

\section{Head 3, Article 1: 'are there two principles, one of good and one of evil?’}

This question is inspired by the dualistic theology-hostile, by report at least, to the world, the church and the body-to which the mediaeval inquisitors gave the name Catharism. ${ }^{26}$ The crusade against the Albigensian Cathars took place in Alexander's youth, and the Dominican order was founded in 1216 to give an intellectual funeral to the heresy which had already been refuted by the sword. ${ }^{27}$ The Franciscans were equally faithful to the church in affirming the goodness of creation (notwithstanding their vows of poverty and celibacy) and in denouncing the Cathars as latter-day Manichaeans; ${ }^{28}$ thus the voice of Augustine, which had silenced their progenitors, dictates that the answer to Alexander's question must be 'no'. ${ }^{29}$ For the proof he returns to Aristotle's five senses of the term 'principle'. ${ }^{30}$ Thus if we mean by a principle that which is more elementary in the order of knowledge, evil cannot be a principle in this sense, as it is always defined by contrast with the good. Again it cannot be a material principle, for evil has no characteristic matter. Nor can it be an initiator of motion, since evil is not an efficient cause but the consequence of deficiency. These three arguments presuppose the understanding of evil as a mutilation of being which has already been established on the authority of Augustine and Dionysius. The fourth argument-that evil cannot be a final cause because the object of willing is always the good-is wholly consonant with the teaching of Dionysius, and with the

25 SH II (n. 2), p. 4a.

26 See Livre des deux principes, ed. Christine Thouzellier, Sources Chrétiennes, 198 (Paris: Cerf, 1973). On the name Cathar see Jan N. Bremmer, The Rise and Fall of the Afterlife (London: Routledge, 2002), 67-70.

27 See Laurence W. Marvin, The Occitan War (Cambridge: Cambridge University Press, 2008).

28 The grounds of the accusation are explained in Steven Runciman, The Mediaeval Manichee (Cambridge: Cambridge University Press, 1947).

29 SH II (n. 3), p. 4b, citing Augustine, On the Customs of the Manichees 3.5.

30 SH II (n. 3), p. 5b. 
Platonic strain in Augustine, but ignores those pathological cases of willing evil as evil which he cites as evidence of the primaeval corruption of human nature. Alexander does not, however, invoke Dionysius by name until he comes to the fifth and final sense of principle as first cause: the pronouncement in the Divine Names that evil is causeless ${ }^{31}$ is somewhat obscurely assumed to preclude its being a cause of other things.

Objections to this assertion of the non-being of evil are drawn from the fact that good and evil are antonyms, and that both are possible objects of volition. Augustine, when he writes with his Pauline rather than his Platonic hand, is the patron of the latter objection, ${ }^{32}$ and hence unanswerable where he himself appears to rebut it. Thus it is he, not Dionysius or Aristotle, whom Alexander repeatedly seeks as his ally when he contends that evil is at most a principle by deficit, and so not equipollent with the good. ${ }^{33}$ Nevertheless, for all the rhetorical efficacy of drawing one's arguments chiefly from a recalcitrant interlocutor, it seems fair to say that Alexander assimilates Augustine to Dionysius (and hence to Aristotle, albeit interpreted in the light of Avicenna ${ }^{34}$ ) not only because it would be impossible to reverse the manoeuvre but because his theodicy cannot allow any substance to evil, on pain of making God the author of sin.

\section{What Then is Evil?}

Although it might seem that the non-existence of evil has already been established, Alexander proceeds to a new heading, 'On evil considered absolutely'. His opening question is: ${ }^{35}$

\section{Book 2 Part 2 Inquiry 1 Treatise 1 Question 1: 'does evil exist?’}

The foregoing arguments might be thought to imply a negative answer to this question, all the more so when Alexander interprets the Johannine dictum, 'without him nothing came into being', to mean that evil is that nothing which came into being without the Word. Statements of the same tenor are adduced from Augustine, Greg-

31 SH II (n. 3), p. 5b, citing DN 4.30 (Suchla, 175.16).

32 SH II (n. 3), p. 6a, citing Question 21 of Augustine's 83 Questions.

33 See especially $S H$ II (n. 3), p. 6b, citing Augustine, City of God 12.7.

34 On the diffusion of Avicenna's works, and their arrival in Paris, see Amos Bertolacci, 'On the Latin Reception of Avicenna's Metaphysics before Albertus Magnus: An Attempt at Periodization,' in The Arabic, Hebrew and Latin Reception of Avicenna's Metaphysics, ed. Dag Nikolaus Hasse and Amos Bertolacci (Berlin: De Gruyter 2012), 197-218.

35 SH III (n. 1), p. 3. 
ory the Great, Isidore and Anselm, but it is Dionysius who supplies a battery of authoritative testimonies to the non-existence of evil:

(a) 'nothing does what it does with the nature of evil as its end'; 36

(b) 'everything that exists is good, insofar as it exists';

(c) 'evil has no substance but is contrary to substance'37

and he proves that evil has no seat in any of the orders of being (angelic, animal, natural, corporeal, material). ${ }^{38}$

But since the thesis that evil does not exist was introduced by the words 'it would seem', we know that we are awaiting the antithesis. Alexander's method, as always, is not to set one author against another but to set text against text from the writings of the same author. Thus Augustine, always the chief authority, bears witness against himself when he identifies the good with order, granting to evil a subordinate status which is something more than nullity, since it testifies to the supremacy of the good. The consilience of Augustine and Dionysius entails that each must echo the other even in his dissonances: we are thus not surprised to hear the latter declaring that 'if there is no evil, virtue and malignity are the same,39-from which it follows, since they are evidently not the same, that evil must exist. Again, he asserts, as clearly as Augustine, that 'what is wholly destitute of good does not exist', ${ }^{40}$ yet he is also at one with Augustine in his conviction that 'nothing evil is wholly destitute of good'. This does not in fact entail that evil exists, unless it is shown that only those things which are destitute of good are non-existent: in concluding that evil must in some sense exist, Alexander has surreptitiously translated a sufficient condition ('if $\mathrm{x}$ is wholly destitute of good, it does not exist') into a necessary condition ('if and only if $\mathrm{x}$ is wholly destitute of good, it does not exist'; or conversely, 'if and only if $\mathrm{x}$ does not exist, it must be wholly destitute of good').

He resolves his own dilemma with the characteristic maxim that there is a sense in which evil exists and another sense in which it does not. It may possess existence by reason, by nature or by custom. Existence in the first sense (esse rationis) is the adequation of a thing with the mind; inasmuch as the mind perceives evil as a deformity in creatures, it has this species of existence. Again, it has esse naturae, 'existence by nature', inasmuch as its natural effects are clearly perceived. On the other hand, inasmuch as it exists by custom, it does not exist, for it does not belong to the world as ordained by God. The meaning of existence by custom (esse moris) will be explained below, under Question 3, Member 1, Head 3.

36 DN 4.19 (Suchla, 163.17-19, cf. 176.15)

37 DN 4.20 (Suchla, 168.11); DN 4.31 (Suchla, 177.1).

38 DN 4.22-30 (Suchla, 169.20-176.8).

39 DN 4.19 (Suchla, 164.4-6).

40 DN 4.33 (Suchla, 178.5-7). 
The four negative assertions of Dionysius are thus to be understood as follows:

(a) While evil does not exist as an end, we cannot deduce from this that it is nonexistent in every other sense.

(b) Dionysius means that a thing is deprived of being only inasmuch as it is deprived of goodness; the point appears to be that the quoted dictum allows for the existence of that which is evil so long as it contains some residual good.

(c) 'Substance' is here to be understood as 'form', and while evil is contrary to form it does not follow that it lacks matter. The notion that matter can exist without form is ascribed by Alexander to Aristotle on the authority of Avicenna.

(d) By 'seat' Dionysius means a natural habitation, and he is therefore saying only that evil has no natural place in any order of being, not that it is nowhere to be found.

Dionysius himself, according to Alexander, clearly acknowledges the ambivalent status of matter: 'it neither exists nor is the efficacious cause of things existent, but exists on account of matter, and is the efficacious cause of things that are good. ${ }^{, 41}$ Alexander adds on his own account that it is one thing to say that evil corrupts and another to say that fire does so, because fire corrupts wood according to its form, i.e. its essence, whereas evil, as mere privation, has no essence and corrupts by impairing the form of another thing. Returning to Augustine's identification of the good with order, he observes that while Dionysius denies both order and place to evil, ${ }^{42}$ he also demonstrates that it is extrinsically subject to order inasmuch as it is made [by God] to be the cause of good. The strife between good and evil, adduced by some as proof that evil is real, is also explained by Dionysius when he observes that that which is opposed to the good opposes it by the power of the good itself. ${ }^{43}$ Hence his considered opinion is that evil is neither in the existent nor in the non-existent but further from the good than the non-existent. ${ }^{44}$ From this we may surmise that Alexander admits a scale of being, as there is a scale of goodness, and that he places evil a little above the bottom of this scale but well below the maximal point which is occupied by the absolute good.

In origin this is a broadly Platonic assumption, and all historians are aware that it reaches its most elaborate form in the writings of Proclus, which were transmitted to the Western church directly in the Liber de Causis, ${ }^{45}$ but only under the name of Aristotle and only after a conduit had been opened surreptitiously by the author

41 Maybe a paraphrase of $D N 4.28$ (Suchla, 177.11 and 18).

$42 D N 4.33$ (Suchla, 178.3-4) and DN 4.34 (Suchla, 178.18).

43 DN 4. 20 (Suchla, 166.7-8).

44 DN 4.19 (Suchla, 164.1-3).

45 See Adriaan Pattin, 'Le liber de causis,' Tijdscrift voor Filosofie 28 (1966): 90 - 203; Thomas Aquinas, Commento al libro delle cause, ed. Christina D’Ancona Costa (Milan: Ruscano, 1986). On the synergy of this text with the thought of Dionysius in Aquinas, see David Burrell and Isabelle Moulin, 'Albert, Aquinas and Dionysius,' Modern Theology 24 (2008). 
who purports to be Dionysius. We cannot maintain that belief in degrees of being is either scriptural or essential to a Christian philosophy, unless we are to deny the Christianity of those who follow Scotus in affirming the univocity of being. It does not follow that the Dionysian strain in mediaeval thought is merely invasive, as though the church had failed to shake off a lingering influenza: like any other element of Christian thought that was not derived immediately from the Scriptures or common experience, it took root only because it was found to be serviceable in defence of scriptural teachings that were deemed to be fundamental, and because it enabled many to reconcile their experience with an intelligent faith in the goodness of God.

\section{Whence Evil, if not From God?}

This discussion is followed by an inquiry concerning the provenance of evil, which necessitates a return to questions already addressed in passing (and perhaps not pertinently) when Alexander asked whether evil can be ranked with good as a principle.

\section{Book 2 Part 2 Inquiry 1 Treatise 1, Question 3 ('Whence is evil?'): Member 1 Head 1: 'does evil have a cause?'}

Alexander begins by stipulating that if it has a cause, this must be either good or evil. The cause of evil, however, cannot be good, for Dionysius assures us that 'it pertains to the good to produce good effects'. ${ }^{46}$ At the same time, the cause cannot be evil because, if evil is a deficiency, its existence must be dependent on something which is not deficient. That is to say, an evil cause must have its own cause, and so if the cause of evil were invariably an evil, we should fall into an infinite regress. Augustine has shown that such a regress can be avoided only by admitting that there is no cause for the abuse of freewill other than the freedom of the will; ${ }^{47}$ Dionysius confirms the antinomy, declaring both that evil is causeless and that, whereas the good has one cause, the causes of evil are many. ${ }^{48}$

46 SH III (n. 3), p. 7a, citing DN 4.23 (Suchla, 171.2-3).

47 SH III (n. 3), p. 7 b.

48 DN 4.31 (Suchla, 176.9-10). 


\section{Question 3 Member 1 Head 2: 'is God or a creature the cause of evil?’}

The former might seem to be true, Alexander observes, inasmuch as the cause of a cause of $\mathrm{X}$ is itself among the causes of $\mathrm{X}$ : hence if evil is caused by freewill, and God is the cause of freewill, it will follow that God himself is among the causes of evil. Again, it is stated by Anselm that God tempts us by not relieving us of temptation, hence it appears that he does indeed will, and therefore causes, evil. ${ }^{49}$ Augustine, however, repeatedly denounces this error, ${ }^{50}$ and so does Dionysius when he affirms that evil is not in God and not a thing moved by God..$^{51}$ The solution is to distinguish between evil as sin and evil as punishment; God is the cause of evil in the latter sense only; ${ }^{52}$ Alexander adds that he may in fact be the cause of evil as sin, but only insofar as sin itself is its own punishment. ${ }^{53}$

\section{Question 3 Member 1 Head 3: 'is evil from the creature as from nothing or as from something?’}

It having been demonstrated that God is not the cause of evil, the blame must be laid at the door of the creature. Augustine repeatedly tells us that creatures are prone to evil insofar as they are from nothing and hence tend to fall back into it. ${ }^{54}$ Dionysius too declares that 'evil is not from good, and if from good it is not evil; for it is no more in the nature of good to produce what is not good than it is in the nature of fire to refrigerate. $^{55}$

Should we infer that the creature is the cause of evil only inasmuch as the creature is nothing? Not so, for Anselm teaches that nothing can be the cause only of nothing. We are to understand that, since a creature is something only insofar as it is good, it does not produce evil as a formal or an efficient cause. ${ }^{56}$ The cause is free will, in itself a good not an evil, which must always be exercised by a creaturely agent. Nevertheless, as the words already quoted from Dionysius imply, the freedom exercised here is not that of acting according to one's nature, but that of failing to do so. Augustine would say that this is no true freedom, since it fails to realise the creature's proper mode of being. If, with Alexander, we take the Franciscan view that our liberty is displayed both in choosing good and in choosing evil, we can argue that the

49 SH III (n. 4), p. 8b, citing Anselm of Canterbury, Fall of the Devil 20.

50 SH III (n. 4), p. 9b, citing Augustine's Question 3 from 83 Questions.

$51 S H$ III (n. 4), p. 9a, citing $D N 4.21$.

52 DN 4.22 (Suchla, 170.6-11).

53 SH III (n. 4), p. 9 a.

54 Especially at Letter called Fundamental 30, cited at $S H$ III (n. 4), p. 10a.

55 SH III (n. 4), p. 10a, citing DN 4.19 (Suchla, 163.9-11).

56 SH III (n. 4), pp. 10b-1a, citing Anselm of Canterbury, Monologion 8. 
product of an evil choice is not exactly nothing: as we saw above, it has esse moris, 'existence by convention', rather than by God's design.

\section{Aquinas and Dionysius on Evil ${ }^{57}$}

Thomas Aquinas, born half a century or somewhat less after Alexander, was in his early years a student of Albert the Great, whose commentary on the Dionysian corpus agrees with Grossesteste against Thomas Gallus in reserving a role for intellect even in the ultimate knowledge of and communion with God..$^{58}$ Aquinas, who acted as Albert's secretary in the composition of this book, went on to write his own commentary on the Divine Names, ${ }^{59}$ which has been characterized as a summary of his 'teachings on the ineffable relation of creator to creatures'. ${ }^{60}$ As he never names his preceptor Albert, nothing can be inferred from his silence regarding Alexander: the following observations on his use of Dionysius in the first three articles of his treatise On Evil are designed only to illustrate the persistence in his theological milieu of the questions raised by his predecessor and of the practice of answering them by setting Dionysius first against, then beside Augustine.

The method of Aquinas is the same as Alexander's, to put a question, advance the reasons that might support the false answer, and then to show why this answer cannot be upheld. The first article of the treatise On Evil is again one of Alexander's questions: 'Is evil an entity?' Two citations from Dionysius imply that it is, for if (as he and Damascene hold) evil is contrary to good as light to darkness, it ought to be as substantial as its contrary; ${ }^{61}$ and if, as he also asserts, it is its nature to corrupt, it must have both a characteristic activity and a proper end. ${ }^{62}$ Nevertheless, Augustine's statement that evil is not a nature but the privation of good, corroborated by his own Glosses on the Johannine affirmation that all that exists is the work of the Logos, suffices to prove that evil cannot be an entity, that is, a substance in its own right. ${ }^{63}$ Thus, Aquinas concludes, we must reject not the words of Dionysius himself, but the fallacious inferences that have been drawn from them. Darkness is the contrary

57 For the text discussed here see Thomas Aquinas, On Evil, trans. Richard Regan, ed. Brian Davies (New York: Oxford University Press, 2003).

58 Albert the Great, Super Dionysium de Divinis Nominibus, in Opera Omnia, vol. 37/1, ed. Paulus Simon (Münster: Aschendorff, 1972).

59 Thomas Aquinas, In librum beati Dionysii de Divinis Nominibus expositio, ed. Ceslas Pera (Turn: Marietti 1950). Aquinas knows, or cherishes, the Divine Names more than any other writing in the corpus.

60 Burrell and Moulin, 'Albert, Aquinas and Dionysius,' 638.

61 Aquinas, On Evil, q. 1, a. 1, obj. 5 (Davies, 55).

62 Aquinas, On Evil, q. 1, a. 1, obj. 8 and obj. 10 (Davies, 56).

63 Aquinas, On Evil, q. 1, a. 1, sed contra 1-3 (Davies, 57), citing Augustine, City of God 9.9 and Tractates on John 1.1. All the Augustinian citations noted here have been identified by Brian Davies in his notes. 
of light only in the sense that we give that name to the potentiality for illumination which remains when the light is obscured; the cause of its obscuration is not the darkness itself, but some other entity. ${ }^{64}$ It cannot be denied, on the other hand, that evil is a cause of corruption: whereas, however, an entity would be an efficient cause, whose effect would be to realise some natural end, the evil which corrupts is merely a formal cause (that is, the deformity of the natural thing which has suffered the corruption) and its consequence is 'not natural but an accident of nature' ${ }^{65}$ Hence the opinion of Dionysius, accurately stated, is that, while evil corrupts, it cannot bring anything into being except insofar as it exists, which means insofar as it retains some goodness. ${ }^{66}$

In this case then, Dionysius is a recognised authority, though not a clear authority for the true answer. For this we rely on Augustine, and in the light of his words we arrive at a true understanding of two Dionysian maxims which might otherwise be misread. Without adducing the same quotations from the Divine Names as Alexander does, Aquinas has raised the same question as to whether the power to corrupt implies existence, and all three authors take it as an axiom that to exist is to participate in the good.

Aquinas goes on to put the question, 'Is there evil in good?', and immediately cites from Dionysius both a dictum and an argument in favour of the false thesis that there is not. Evil, declares the Greek saint, is neither an existent thing nor found in things existent, and the syllogism by which he proves it is: 'all that exists is good; there is no evil in good; hence there is no evil in anything that exists. ${ }^{96}$ Again he appears to be at a disadvantage to Augustine, whose argument that since evil is a privation of good, it exists only as a parasite to the good is clearly endorsed by Aquinas himself. ${ }^{68}$ In the ensuing discussion, he hints that Dionysius may have been too ready to join the Platonists in identifying privation with matter and both of these with absolute non-being; his error would thus consist in failing to grasp that a material thing has its own concrete reality, and that evil, as privation of form, can be present in it only because it retains this concrete existence as a material thing. ${ }^{69}$ In his conclusion, however, the apparent contradiction between Dionysius and Augustine is resolved by ascribing to both of them a distinction between the 'intrinsic' existence of a real entity and the accidental existence of that which is present in an entity as privation. ${ }^{70}$ Once again, Augustine is sovereign; once again, he and

64 Aquinas, On Evil, q. 1, a. 1, ad 6 (Davies, 60).

65 Aquinas, On Evil, q. 1, a. 1, ad 10 (Davies, 60).

66 Aquinas, On Evil, q. 1, a. 1, ad 16 (Davies, 62), citing DN 4.20 (Suchla, 165.6-8).

67 Aquinas, On Evil, q. 1, a. 2, obj. 1 (Davies, 62), again citing DN 4.20 (Suchla, 166.9-10).

68 Aquinas, On Evil, q. 1, a. 2, sed contra 1-2 (Davies, 62), citing Enchiridion 14 and 11. Enchiridion 12 has already been cited at a. 2, obj. 16 (Davies, 62) as an apparent testimony to the reality of evil as the power which opposes the good.

69 Aquinas, On Evil, q. 1, a. 2, resp (Davies, 65).

70 Aquinas, On Evil, q. 1, a. 2, ad 1 (Davies, 66); cf. ad 3, alluding to DN 4.21. 
Dionysius are found to agree, this time at the expense of Plato. And once again, the quotation of Dionysius, though not its application by Aquinas, has a precedent in the Summa Halensis.

The third inquiry, 'Is good the cause of evil?', appears at first to be answered in the negative (and falsely) by a statement in the Divine Names that evil does not proceed from good and that whatever proceeds from good cannot be evil. ${ }^{71}$ In this case, however, he seems to make common cause against his own thesis with Augustine, for where the latter opines that only good can be the origin of evil, the Divine Names speaks of the good as both its origin and its end..$^{72}$ The solution, as we might have foreseen, is that Dionysius holds good to be the source of evil accidentally rather than intrinsically; the distinction is elucidated by his own saying that the evil effects of an action lie outside the intention of the agent and outside the action itself, inasmuch as the evil is never a necessary result of the act considered simply as movement. ${ }^{73}$ Here, therefore, Aquinas follows Alexander's rule of citing Dionysius not only against but in favour of the true thesis; his agreement with Augustine is explicit, and implies, as in Alexander, that the Platonism of Dionysius sometimes corrects the Pauline strain in the Latin father just as in other cases the latter corrects the Platonism of Dionysius.

\section{Coda}

Aquinas, therefore, does not in all respects concur with Alexander either in his reading of Dionysius or in his solutions to questions concerning the reality of evil. He can say, for example, that evil is a formal but not an efficient cause, while Alexander locates the causality in the creature's will. Evil, while it is not in the proper sense a nature, has some shadow of being inasmuch as it is the consequence of the misuse of rational freedom, which is in itself a good. While the causes of this misdirection remain obscure in Alexander as in Aquinas, they agree that it is rare to be a knowing and deliberate cause of that which one holds to be evil, and that no evil can be directly willed by God in his absolute goodness. It is not God who causes the wrongdoing that he foresees, but the willing agent, though the later may act without the same degree of foresight and moral understanding; since agency implies existence, of which God alone is the author, it follows that the cause and precondition of evil is always in itself good.

71 Aquinas, On Evil, q. 1, a. 3, obj. 5 (Davies, 68), citing DN 4.19 (Suchla, 163.9-10).

72 Aquinas, On Evil, q. 1, a. 3, sed contra 1-2 (Davies, 70), citing Enchiridion 14 and DN 4.31 (Suchla, 176.14).

73 Aquinas, On Evil, q. 1, a. 3, ad 5 and ad 14 (Davies, 72-4), citing DN 4.31-2. 